\title{
Risk Assessment Health and Safety of Acid Recovery unit of Abadan Oil Refining Company by using William Fine
}

\author{
Salman Hafezi ${ }^{1}$, Soolmaz Dashti ${ }^{2}$, Gholamreza Sabzghabaei ${ }^{3}$ \\ 1. Department of Environment, Ahvaz Branch, Islamic Azad University, Ahvaz, Iran \\ 2. Assistant Professor, Department of Environment, Ahvaz Branch, Islamic Azad University, Ahvaz, Iran \\ 3. Assistant Professor, Department of Environment, Behbahan Khatam Alanbia University of Technology, \\ Behbahan, Iran \\ *E-mail: Soolmazdashti@iauahvaz.ac.ir
}

Received: 26 May 2018 ; Accepted: 22 Sep 2018

\begin{abstract}
Background: In today's world, the main issue is the safeguarding of the human resources employed in the economic sectors. But still, it's still yearly Lots of manpower employed Due to human economic activities are destroying. The purpose of this research is to identify hazard points and potentials and risk assessment and provide management solutions to reduce or eliminate these risks in the acid recovery unit of the Abadan Oil Refining Company as one of the most active and important sectors in the oil industry.

Methods: To this end, the William fine method was used in 2016.

Results: Based on the results of this method, 100 hazard and health risks were identified in the acid recovery unit, which included 25 abnormal risks, 2 emergencies and 73 natural risks. The highest RPN in the William fine method with a score of 300 is for the inhalation of acid neutralization gases, and the lowest with a score of 2.5 is the risk of falling from the height. Similarly, of the identified risks, $67 \%$ of the risks are at a low level.

Conclusion: Regarding all mentioned points, the acid recovery unit of ABADAN Oil Refining Company has been identified as medium-average unit. Given the risk management practices, especially the training of personnel in different sectors, the formation of an accident investigation team and the scientific analysis of accidents and pseudo-events will play an important role in reducing the overall system risk
\end{abstract}

Keywords: Risk Assessment, Acid Reactivation Unit, Abadan Oil Refining Company, William Fine 


\title{
ارزيابى ريسك ايمنى و بهداشت واحد احياى اسيد شركت يالايش نفت آبادان به روش ويليامفاين
}

\author{
سلمان حافظى'، سولماز دشتى "م، غلامرضا سبزقبايى" \\ كروه محيط زيست، واحد اهواز، دانشخاه آزاد اسلامى، اهواز، ايران

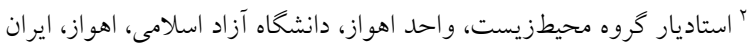

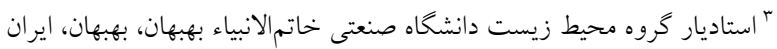

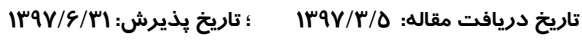

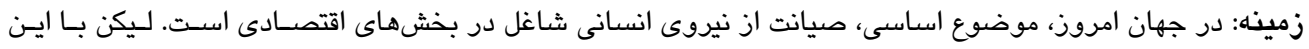

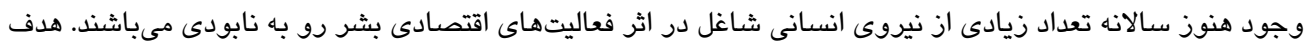

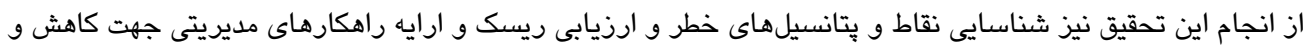

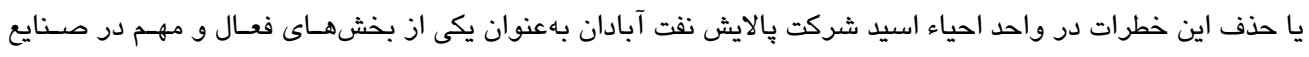
نفتى مى باشد.

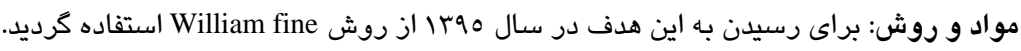

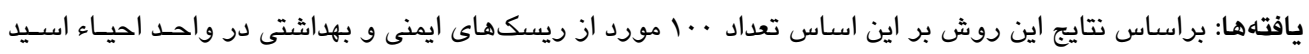

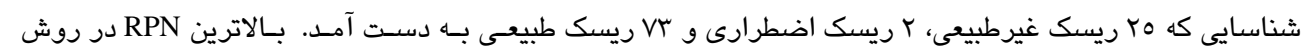
Wبا نمره ..William fine

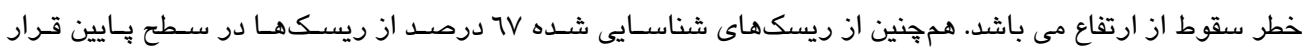
كرفتهاند.

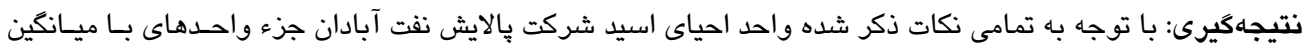

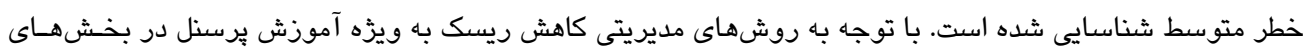

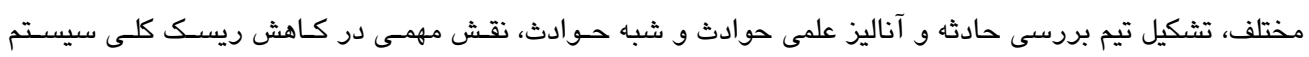
خواهد داشت. كلمات كليدى: ارزيابى ريسك، واحد احياء اسيد، شركت بالايش نفت آبادان، ويليام فاين 
ارزيابى ريسك كه در قادر است ارزيابى دقيق از ميزان ريسك با تلفيق سه بارامتر شدت، احتمال و احتمال تماس داشته باشد

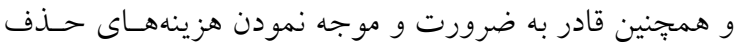

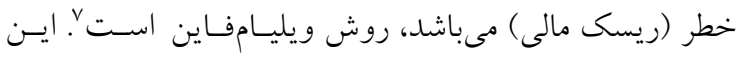

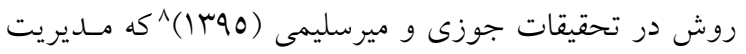

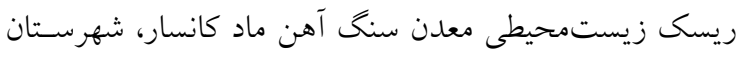

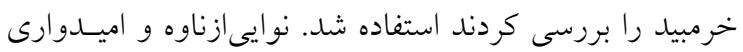

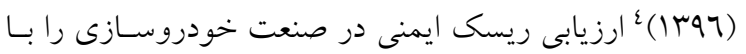
اين روش مورد تجزيسه و تحليـل قـرار دادنــــ در كارخانسهى

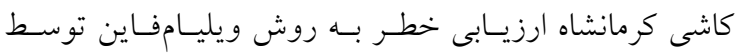

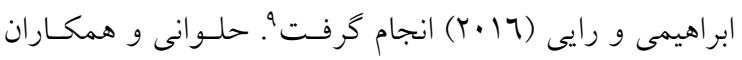

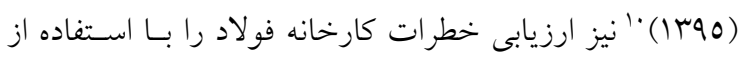

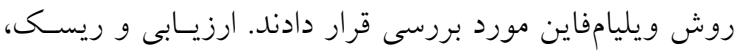
ايمنى، بهداشت و مديريت زيستمحيطى دستخاههاى حفـارى

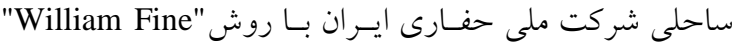

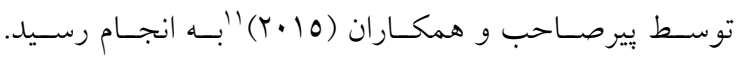

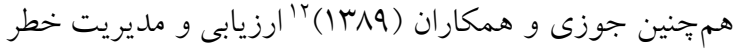
ايمنى، بهداشتى و زيستمحيطى شركت لولهسـازى اهـواز بــهـ

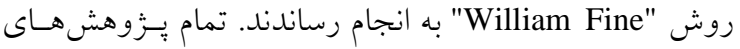
بيـان شــده كـاريى بـالاى روش William Fine در صـنايع مختلف بيان مى كنند. زيرا اين تكنيك به مديران كمك مى كنــ كه با اولويتبندى برنامههاى كنترل خطر ات و حوادث و تعيين

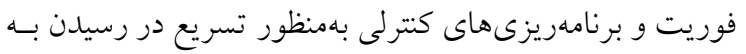

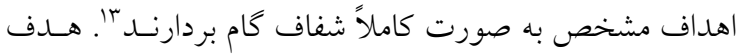
از كاربرد اين تكنيك تعيـين يـك روش بـراى تصـميم گيــرى

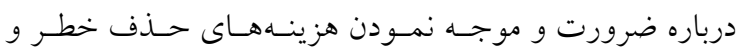

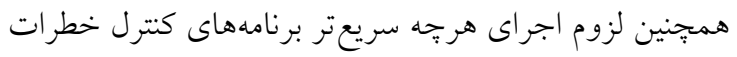

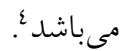
واحد احياى اسيد شـركت پـالايش نفـت آبـادان يكسى از

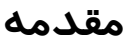

شواهل موجود در كشـورهاى صـنعتى و در حسال توسـعه

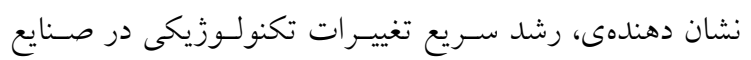

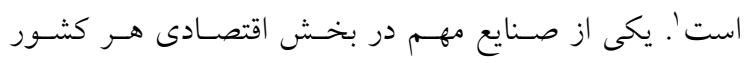

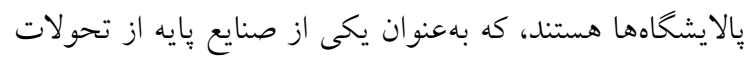

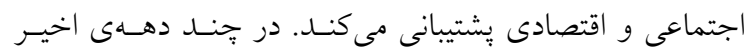

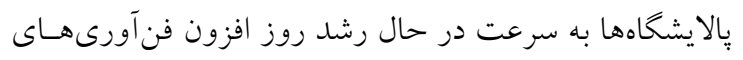

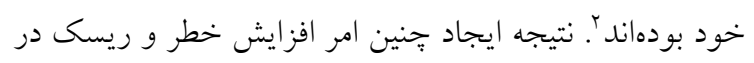

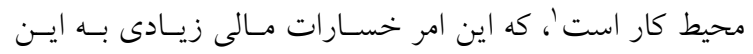

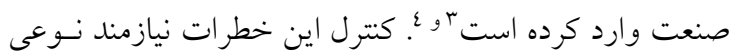
سيستم مديريتى است كه منجر به كاهش اين خطرات و حصول

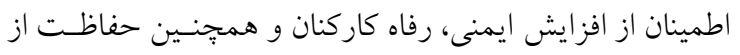

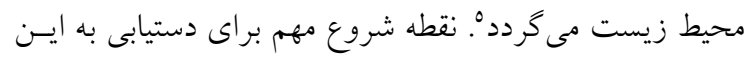

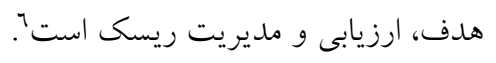

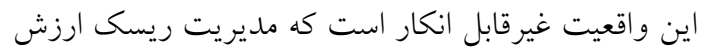

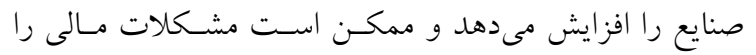

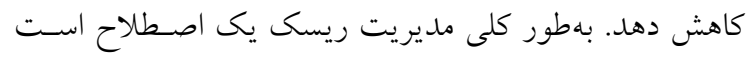

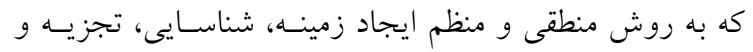
تحليل، درمان، نظارت و ارتباط خطرات مربوط به هر فعاليت،

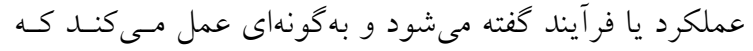

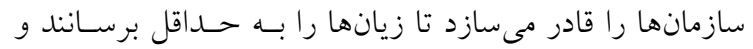

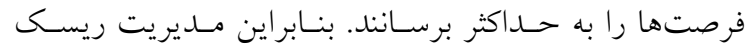

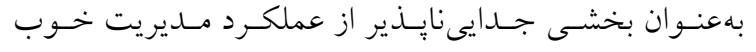
شناخته مى شودّ". امروزه مى توان در مديريت ريسك با استفاده از روشهاى شناسايى خطرات و ارزيابى ريسك، نقاط حادثهزا

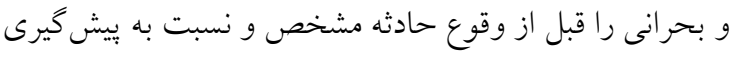

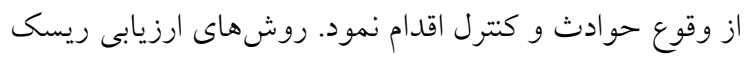

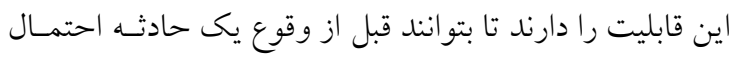

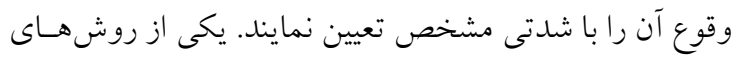


دسترسى آن به آبهاى آزاد جايخاه مهمى در اقتصاد كشور به

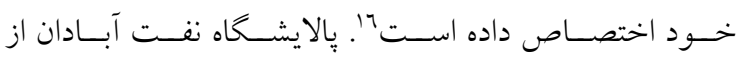
واحدهاى مختلفى براى فرآورى نفـت و متلغـات آن تشكيل

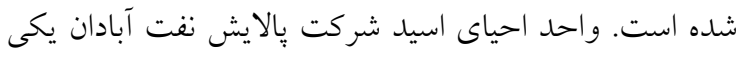

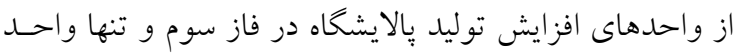
احياى اسيد در سطح كشور و خاورميانه مى باشد، كه در سـال

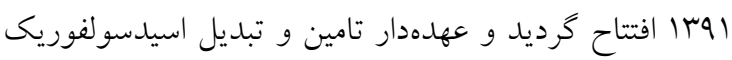

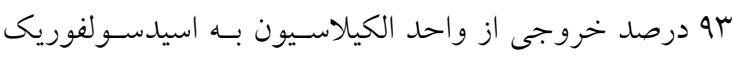

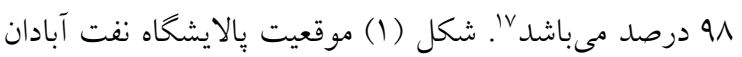
را نشان مىدهل، كه از شمال بـهـ كـوى قـــس، از جنـوب بــــ

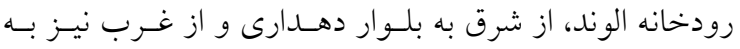
خيابان يتروشيمى منتهى مى نوده.

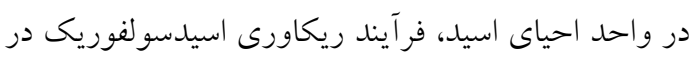

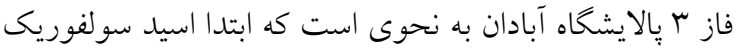

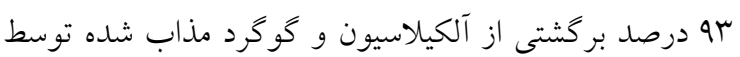
بخار در حوضجه مذاب را در كوره (H-1601) تا دماى 70 -1

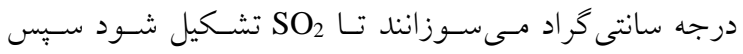
B- محصولات حاصله از احتراق از خروجى كوره بـهـ بـويلر

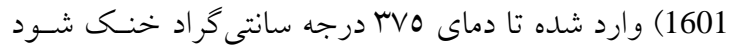
يس از آن وارد اسكرابر (V-1601) جهت تميز و خنكى كـردن كاز SO از محصو ان وارد النات ديخر نظير آب شود.

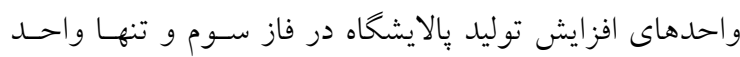

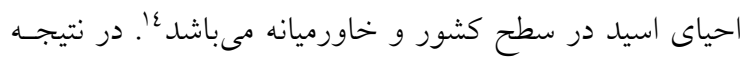
فرآيند احياى اسيد در واحد اسيد شركت بِالايش نفـت آبـادان همانند ساير محيطهاى صنعتى به دليل ماهيت و نوع فعاليتها

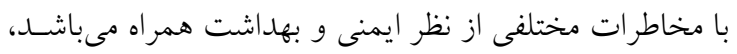

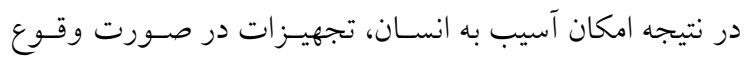

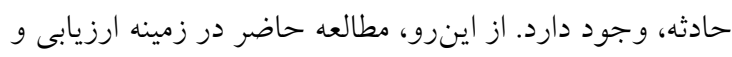

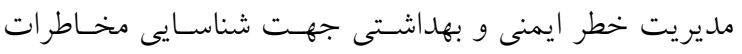

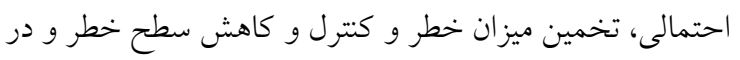

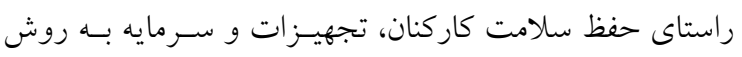
William Fine

\section{روش تحقيق} منطقه مورد مطالعه

شهرستان آبادان، در •ال اليلومترى اهواز در دهانسه ورودى

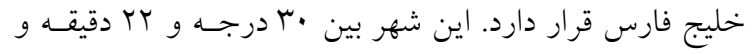

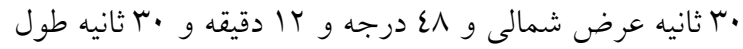

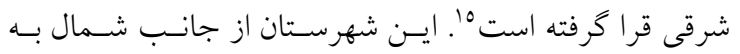
شهرستانهاى شادگان و خرمشهر از شرق بـه شهرسـتان بنــر

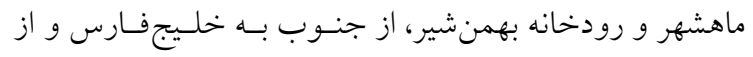

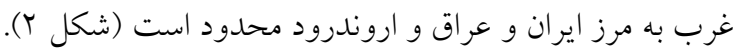

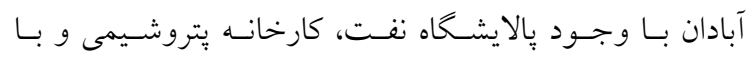




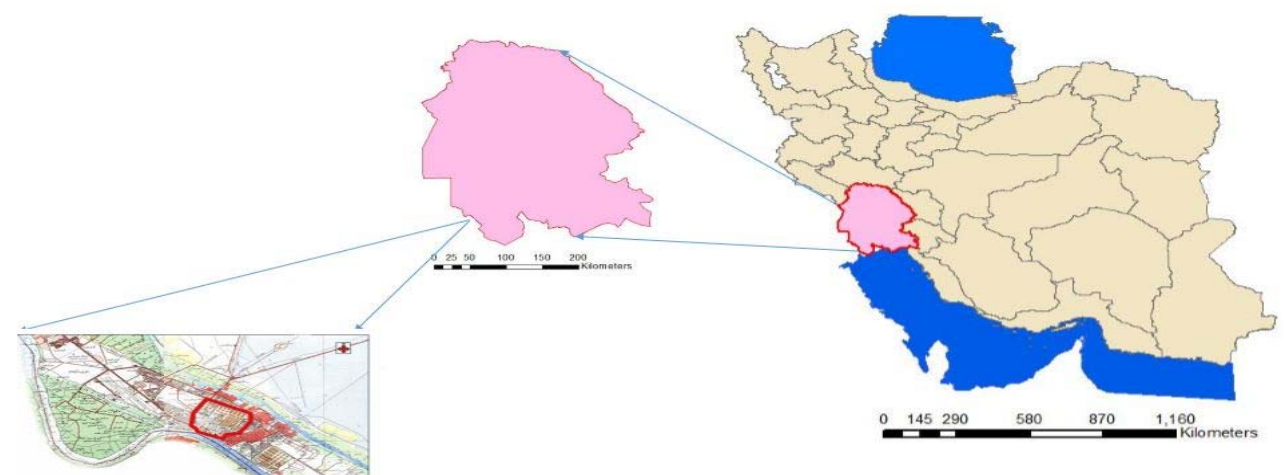

شكل ا: موقعيت جغرافيايى منطقه مورد مطالعه

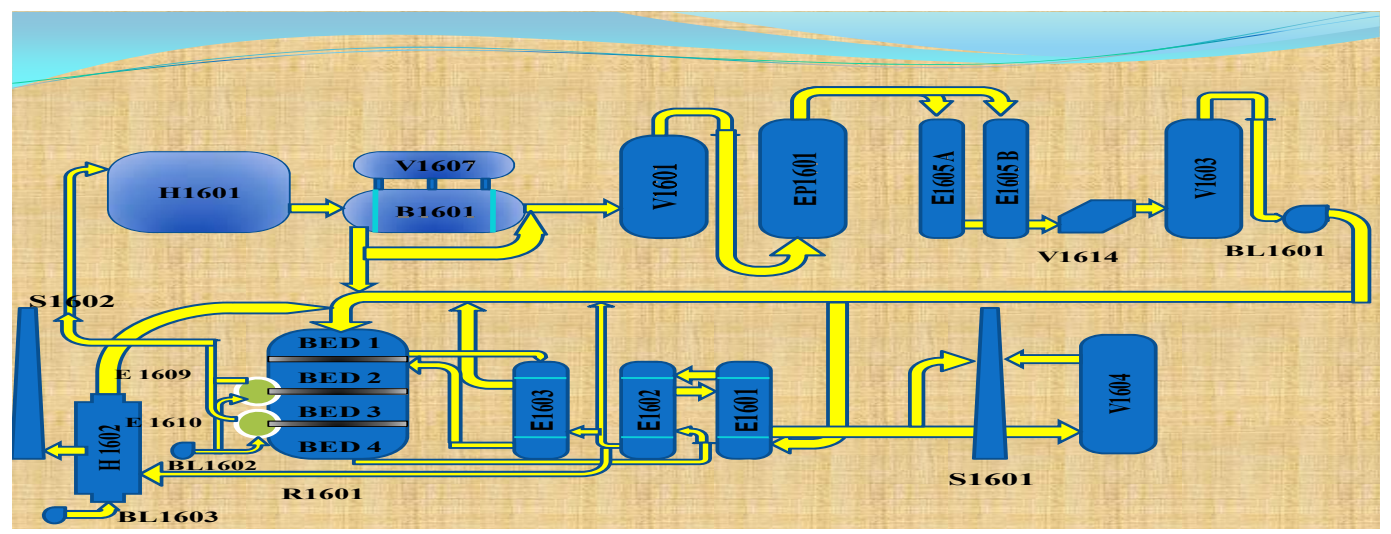

شكل r: فرايند واحد اسيد در يك نغاه 19

كاتاليستهاى موجود در جهار بستر راكتور كه از جـنس ينتـا اكسيد واناديوم (V) مى كـردد. يُس از آن خـاز SO $\mathrm{SO}_{3}$ كه در اين برج با اسـيد (Absorption Tower V-1604) موجود در برج واكنش داده و تبديل به اسيد 99/0٪ مى گردد

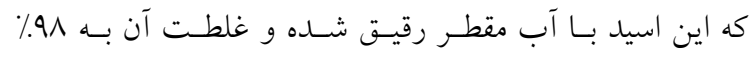
مىرسد كه همان محصول واحسـ اسـت و ايسن اسـيد بوسـيله

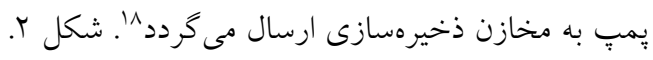

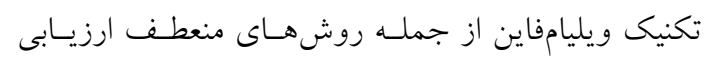
ريسكهاى محيطزيستى، بهداشتى و اقتصادى ناشى از فعاليت واحد صنعتى شناخته مىشود كه در سامانه مديريت بهداشـت
يسّ از اسـكرابر وارد (EP-1601) ) شـــ ACID MIST·PRESPETAT يونيزاسيون ايجاد شده توسط المنتهاى الكتريكى كه با ولتـاز

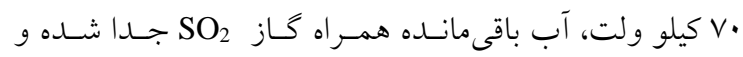
كاز (V-1603) شــده و يـس از آن وارد دمنــده مسى شـود (ضـمنا

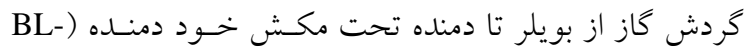
1601) بوده است به عبارتى فشار واحد تا ورودى دمنده منفى مىباشد) يس از عبور از دمنده وارد سه مبـدل حرارتسى شـده

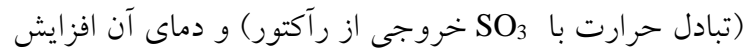
يافته و وارد راكتور (R-1601) مى شود، بعد از آن گاز SO بـا 
مرحله سوم: در اين مرحله ريسكهاى بهداشـتى و ايمنسى موجود در واحد احياى اسيد شناسـايى شـــ. مرحلـه جهـارم: براى امتيازدهى به ريسكهاى شناسايى شده در واحد احيـاى اسيد بايد رتبهبندى شدت اثر (جدول ا)، رتبـهبنـدى احتمـال وقوع (جدول r) و رتبـهبنـدى مواجهـه/ تمـاس (جــول r) صورت كرفت. هر كدام از عوامل، با توجه به شرايط موجـود بر اساس جداول ييشـنهادى ويليـامفـاين توسـط كارشناسـان

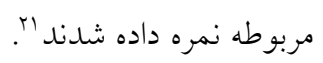
مرحله ينجم: سبس از حاصل ضرب سـه فـاكتور احتمـال وقوع، مواجهه / تماس و شدت اثر ضـريب ريسكى بـهدست

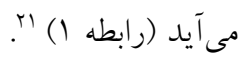

رابطه (1) مواجهه/تماس × احتمال وقوع × شدت= ضريب ريسك در نهايت با استفاده از نمــرهى ريسـى حاصـله اقــدامات

$$
\text { كنترلى تعيين كرديد (جدول ع). }
$$

و ايمنى از جمله روشهاى متواتر به حساب مى آيد ". از ايـن

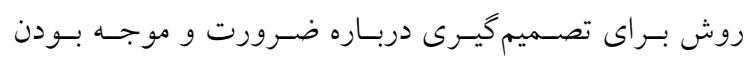

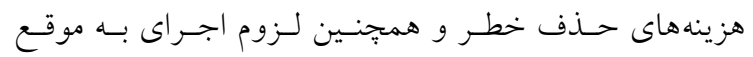

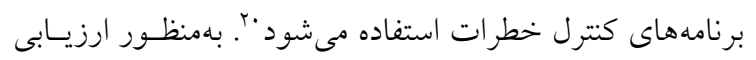
ريسك به وسيلهى اين تكنيك، مراحل زير صورت گرفت. مرحله اول: در ابتدا به وسيلهى بازديدهاى ميدانى، محسيط

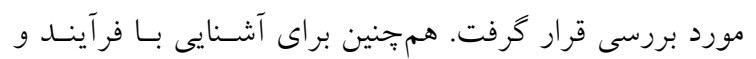
تجهيزات مورد استفاده در واحسـد احيـاء اسـيد بـا كارشناسـان فرآيند احياى اسيد، كارشناس بخش ايمنى و برخى از برسـنل فعال در بخشهاى مختلف واحسـ صـحبت و مشـاوره شـد و اطلاعات مذكور جمع آورى گرديد. مرحلـه دوم: يسس از بررسـى و شناسـايى مـوارد فـوق، مطالعاتى در مورد صنعت احيـاى اسـيد، سـابقه كـار واحسـد و سوابق كذشته موارد حوادث بيش آمده در اين واحد صـورت مورت كرفت.

\begin{tabular}{|c|c|c|c|c|c|}
\hline 1 & $r$ & $r$ & 7 & 1. & نرخ \\
\hline 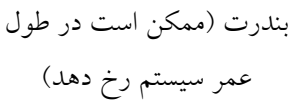 & يكبار در سال & كاه به گاه & $\begin{array}{c}\text { (يكبار در روز) مكرر })\end{array}$ & 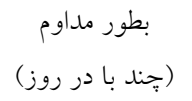 & طبقهبندى \\
\hline
\end{tabular}

جدول ا: ميزان مواجهه

\begin{tabular}{|c|c|}
\hline 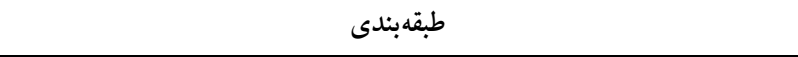 & نرخ \\
\hline مرگ و مير متعدد - توقف طولانى فعاليت - فاجعه بار & $1 \cdots$ \\
\hline 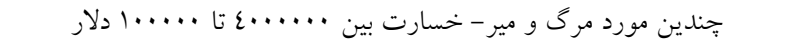 & 0. \\
\hline 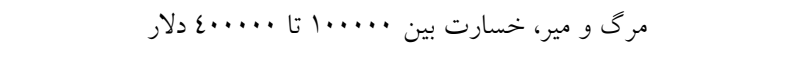 & ro \\
\hline 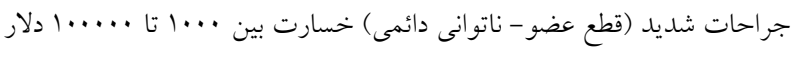 & 10 \\
\hline جراحات متوسط -خسارات تا ...1 دلار & 0 \\
\hline جراحات و خسارات اندى & 1 \\
\hline
\end{tabular}

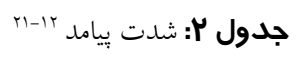

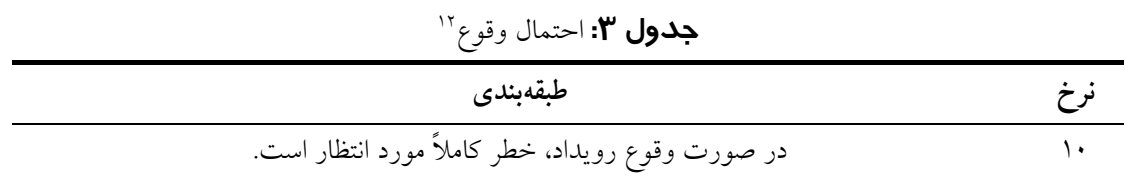


ارزيابى ريسك ايمنى و بهداشت واحد احياى اسيد شركت پالايش نفت آبادان به روش ويليامفاين

$$
\begin{aligned}
& 7
\end{aligned}
$$

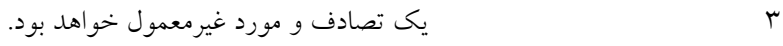

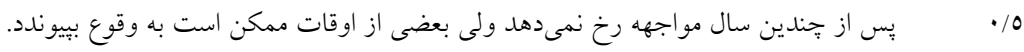

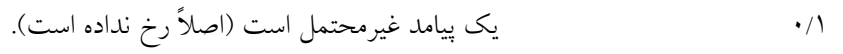

\begin{tabular}{|c|c|c|}
\hline \multicolumn{3}{|c|}{ جدول ع: نمره ريسك و اقدامات كنترلى بr } \\
\hline \multicolumn{2}{|l|}{ 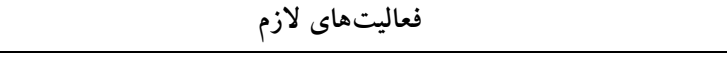 } & نرخ \\
\hline \multirow{3}{*}{\multicolumn{2}{|c|}{ 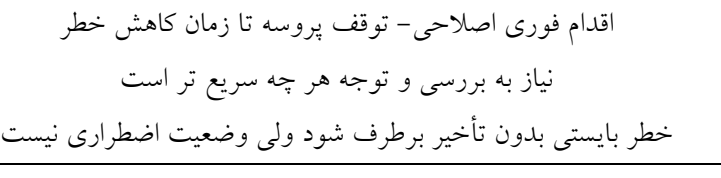 }} & $10 \cdots-r \cdots$ \\
\hline & & $199-9$. \\
\hline & & $\wedge q_{-} \cdot$ \\
\hline \multicolumn{3}{|c|}{ جدول ठ: هزينه تخمينى براى فعاليتهاى اصلاحى(CF) } \\
\hline طبقه بندى & نرخ & \\
\hline بيشتر از ...... دلار & 1. & \\
\hline 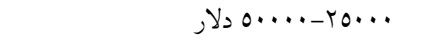 & 7 & \\
\hline 的 & $\varepsilon$ & \\
\hline 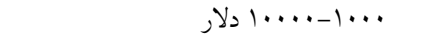 & r & \\
\hline ....... & r & \\
\hline (... & 1 & \\
\hline زير 0r دلار & $\cdot 10$ & \\
\hline
\end{tabular}

نمره ريسك، ميزان هزينههاى قابل قبول از رابطهى (Y) محاسبه

$$
\begin{aligned}
& J=\frac{R}{D F \times C F} \\
& \text { در اين فرمول R ميزان هزينه قابل قبول، CF نمره ريسك، } \\
& \text { DC }
\end{aligned}
$$

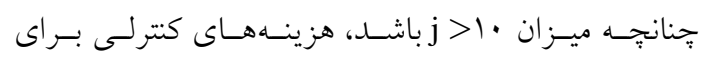

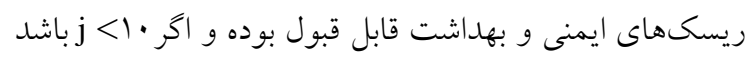

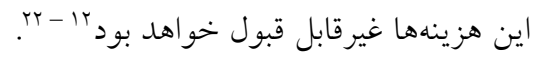

\section{نتايج}

\begin{tabular}{|c|c|}
\hline طبقه بندى & نرخ \\
\hline به ميزان . 1٪ خطر حذف مىشود & 1 \\
\hline حداقل V0\% خطر حذف مىشود & r \\
\hline 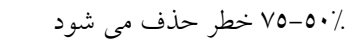 & r \\
\hline 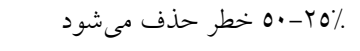 & $\varepsilon$ \\
\hline 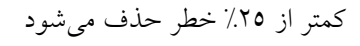 & 7 \\
\hline
\end{tabular}

با توجه به نتايج به دست آمده دو ريسك بازديد و بررسى

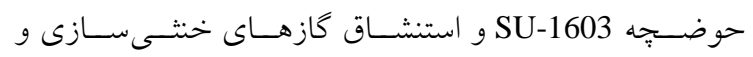

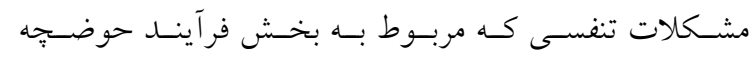

از آنجايى كه روش ويليامفاين، يكى از روشهاى بررسى

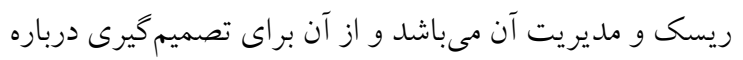
ضرورت و موجه بودن هزينههاى حذف خطر و همجنين لزوم اجراى هر جهه سـريع تـر برنامـهـــاى كنتـرل خطـرات اسـتفاده

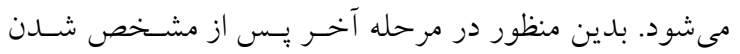


متوسط قرار دارند كه براى ريسكهـاى متوسـط راهكارهـاى

$$
\text { كنترلى بيشنهاد كرديد (جدول V). }
$$

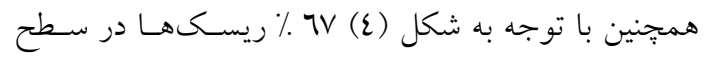
ريسكيذيرى يَايينى قرار دارند و سب/\% از ريسكهـا در سـطح بحرانى و متوسط قـرار دارنــ، كـه RPNهـاى ثانويـه تمـامى

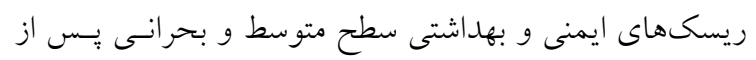

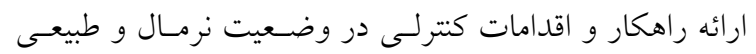

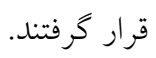

خنتى سازى آبكولينگ و گو گرد مىباشد و ريسك عمليـات تخليه تانكر حمل اسيد بـه مخـازن و احتمـال نشـتى اسـيد و سوختكى نفرات كه در بخش فرآيند مسير خوراك است، جز ريسكهاى اضطر ارى مىباشد (جدول ^). در بخـش فراينـدهاى ورودىهاى كوره، مسير گردش اسيد ضـعيف بـه كـوره،

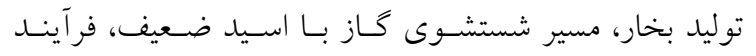

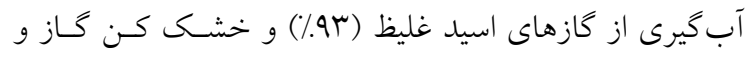
هوا، مسير بيش گرم كن خوراى راكتور، مسير گردشى و توليد

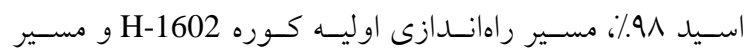
خروجى اسيد 91٪ محصول تمامى ريسكها در سطح پايين و جدول V: شناسايى ريسكهاى ايمنى و بهاشت شغلى واحد احياء اسيد در وضعيت خطر طبيعى 


$$
\begin{aligned}
& \text { ارزيابى ريسك ايمنى و بهداشت واحد احياى اسيد شركت پالايش نفت آبادان به روش ويليامفاين } \\
& \text { P-1603 و استنشاق تنفسى } \\
& \text { بخارات اسيد } \\
& \text { بازديد و بررسى بويلر بحارت }
\end{aligned}
$$

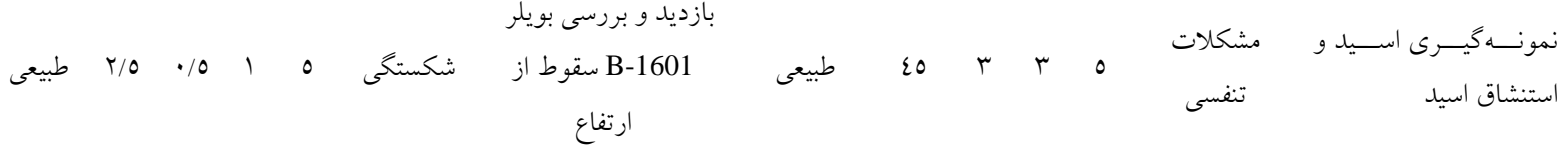

$$
\begin{aligned}
& \text { بازديد و بررسى بويلر }
\end{aligned}
$$

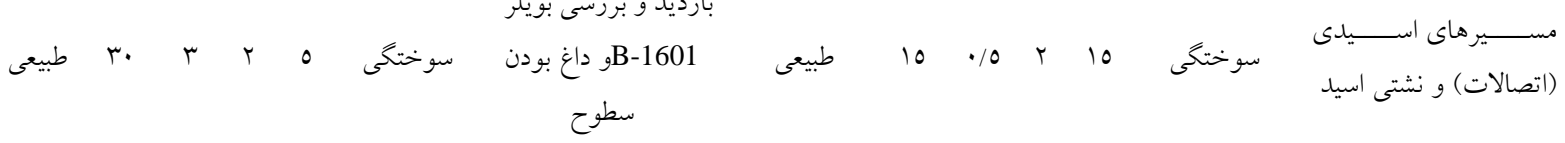

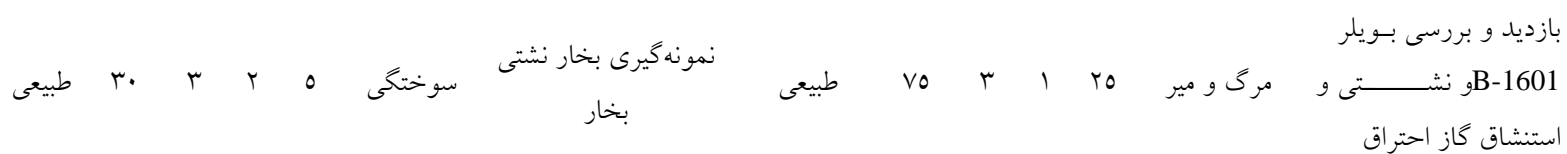

$$
\begin{aligned}
& \text { بازديسـ و بررسسى مبــارل }
\end{aligned}
$$

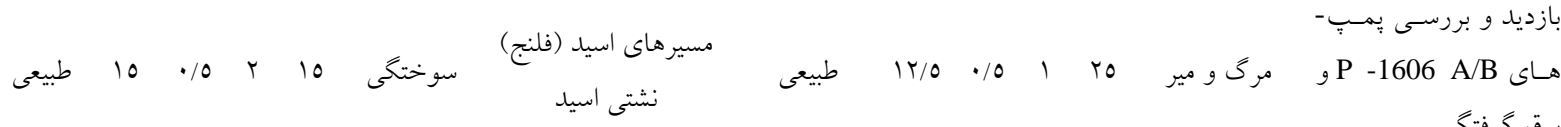

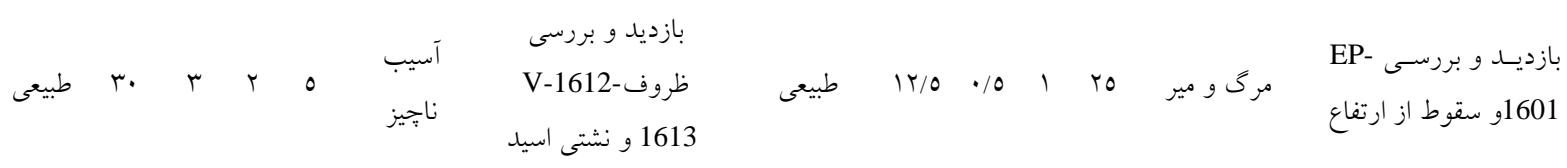

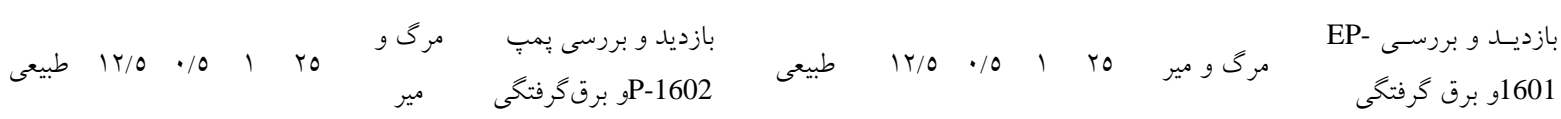

$$
\begin{aligned}
& \text { كاز } \\
& \text { بازديد و بررسى مبـدل } \\
& \text { ارتفاع }
\end{aligned}
$$

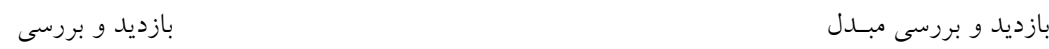

$$
\begin{aligned}
& \text { استنشاق كاز } \\
& \text { ارتفاع } \\
& \text { بازديد و بررسى ظرف }
\end{aligned}
$$




$$
\begin{aligned}
& \text { BL-1601 } \\
& \text { كرفتيخى }
\end{aligned}
$$

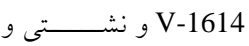

$$
\begin{aligned}
& \text { استشاق كاز مرى و مير } \\
& \text { بازديد و بررسى ظـرف } \\
& \text { كاز و } \\
& \text { نمونه كيرى از ظرف - V- }
\end{aligned}
$$

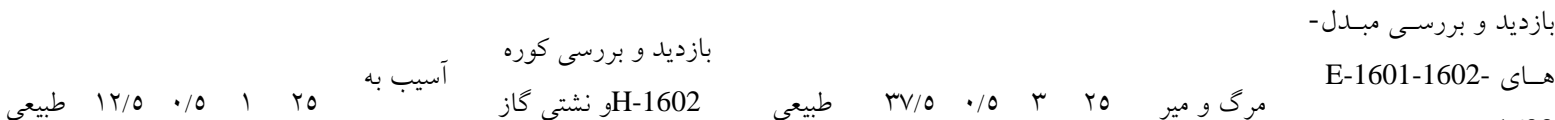

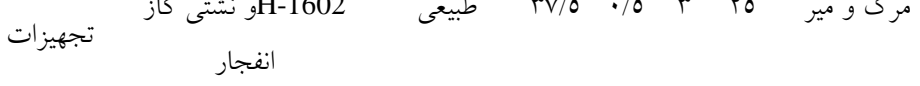

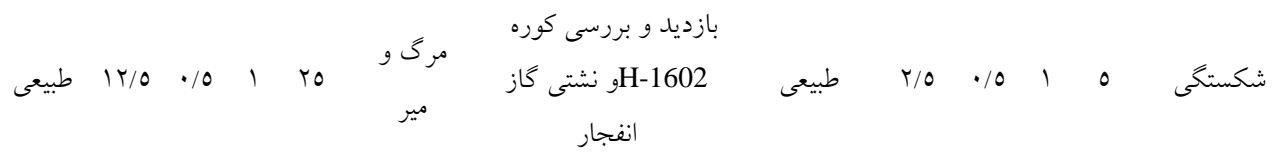

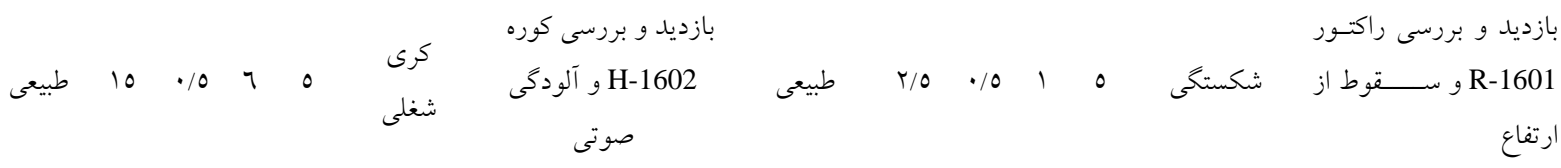

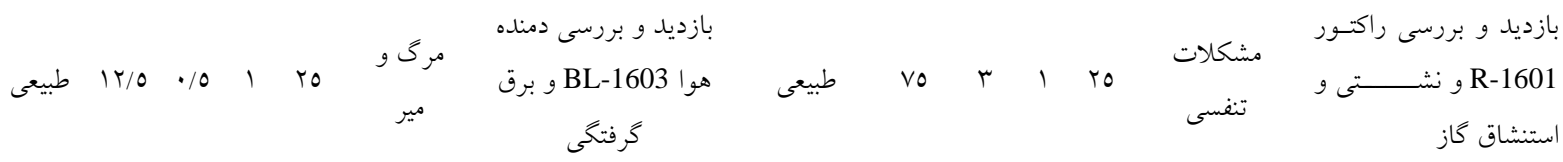

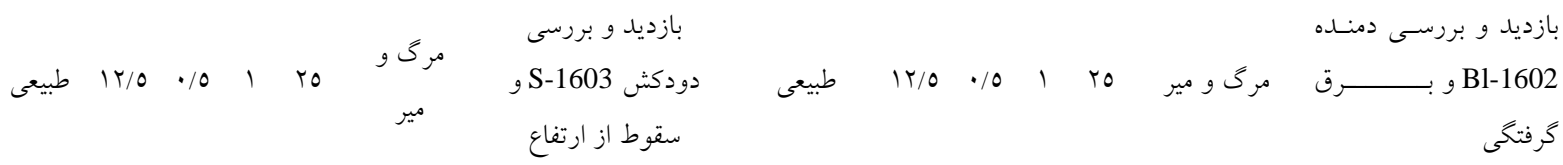

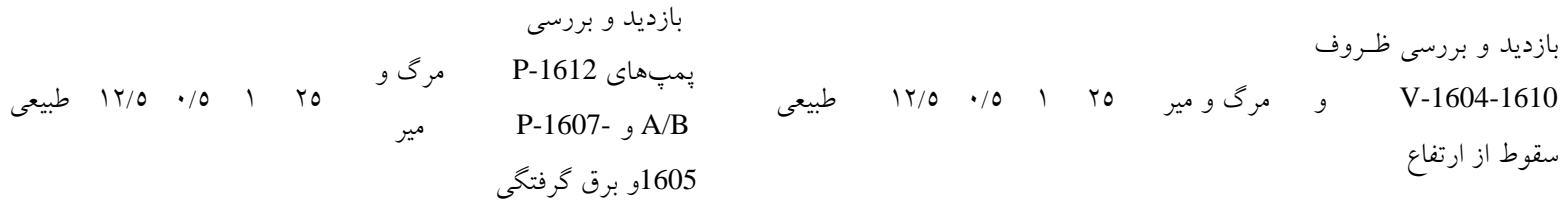

$$
\begin{aligned}
& \text { بازديد و بررسى } \\
& \text { و استشاق كاز } \\
& \text { ارتفاع }
\end{aligned}
$$

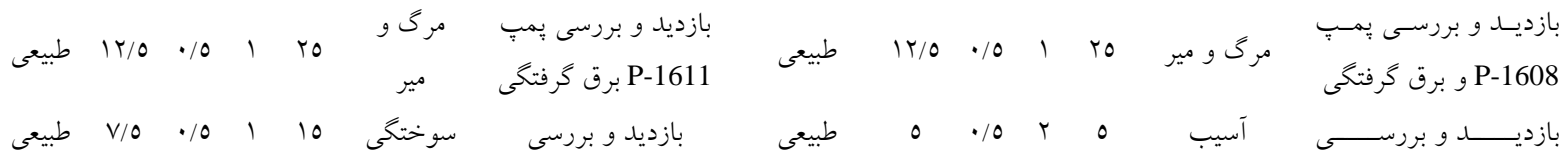


ارزيابى ريسك ايمنى و بهداشت واحد احياى اسيد شركت پالايش نفت آبادان به روش ويليامفاين

$$
\begin{aligned}
& \text { حوضجه SU-1601 و }
\end{aligned}
$$

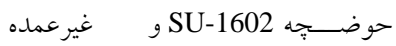

$$
\begin{aligned}
& \text { سقوط در حوضحه } \\
& \text { سقوط در حوضجه آبى } \\
& \text { كو كرد مذاب }
\end{aligned}
$$

\begin{tabular}{|c|c|c|c|c|c|c|c|c|c|c|c|c|c|c|}
\hline \multirow{2}{*}{ توجيرى } & \multirow{2}{*}{$\mathbf{J}$} & \multirow{2}{*}{ هز ينه } & \multicolumn{5}{|c|}{ RPN2 } & \multirow{2}{*}{ خطر } & \multirow[b]{2}{*}{$\mathbf{R}$} & \multirow[b]{2}{*}{$\mathbf{P}$} & \multicolumn{2}{|c|}{ RPN1 } & \multirow{2}{*}{ ييامد } & \multirow{2}{*}{ شرح خطر } \\
\hline & & & $\mathbf{R}$ & $\mathbf{P}$ & $\mathbf{E}$ & C & נוסטה & & & & $\mathbf{E}$ & C & & \\
\hline$\sqrt{ }$ & 10 & $0 / \cdots$ & ¿o & r & 1 & 10 & فنى منظم و روتين بازرسىهـاى & غير طبيعى & 9. & $r$ & r & 10 & & 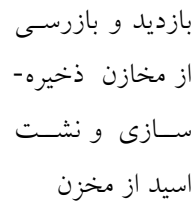 \\
\hline$\sqrt{ }$ & $1 Y / 0$ & $1 \cdots / \cdots$ & 10 & $\cdot 10$ & r & 10 & 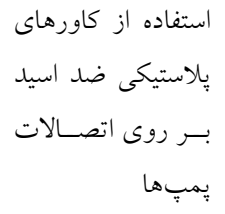 & غير طبيعى & iro & $r$ & $r$ & 10 & & 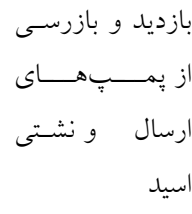 \\
\hline$\sqrt{ }$ & 10 & $0 . / \cdots$ & 11 & 7 & r & 1 & 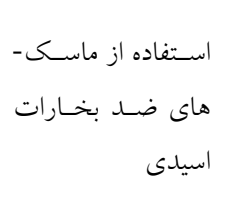 & غير طبيعى & 9. & 7 & $r$ & 0 & تشكلات & 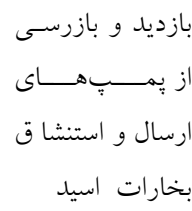 \\
\hline$\sqrt{ }$ & ir & $1 \cdots / \cdots$ & 10 & $\cdot 10$ & r & 10 & بلاستفاده از كاورهاى & غيرطبيعى & 9. & r & r & 10 & & 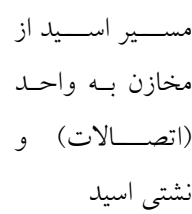 \\
\hline$\sqrt{ }$ & $r Y / O$ & $r \vee / .$. & ¿o & $r$ & $r$ & 0 & 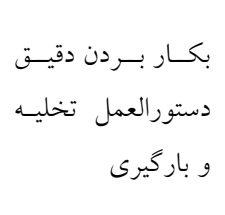 & اضطر ارى & rV. & 7 & $r$ & 10 & & 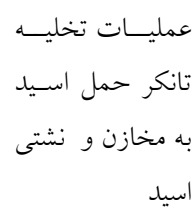 \\
\hline$\sqrt{ }$ & $1 \varepsilon / 0$ & $0 \cdots / \cdots$ & 7 & $r$ & r & 1 & در برابر اتاقـى عـايق & غير طبيعى & 9. & 7 & $r$ & 0 & شغلى كـــــ & 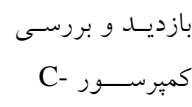 \\
\hline
\end{tabular}

$$
\begin{aligned}
& \text { بازديسـ و بررسسى يمست }
\end{aligned}
$$

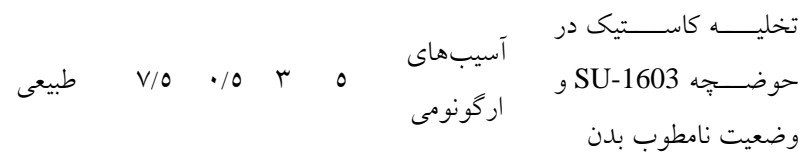

جدول 1: شناسايى ريسكهاى ايمنى و بهداشت شغلى واحد احياء اسيد در وضعيت خطرغير طبيعى و اضطر ارى 


$$
\begin{aligned}
& \text { سلمان حافظى و همكاران }
\end{aligned}
$$

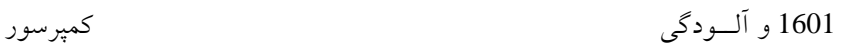

$$
\begin{aligned}
& \sqrt{ }
\end{aligned}
$$

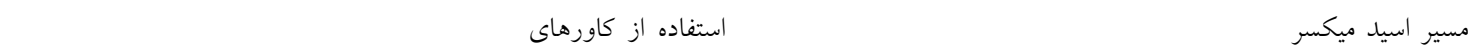

$$
\begin{aligned}
& \text { 1 Me } \quad \text { ME-1602 }
\end{aligned}
$$

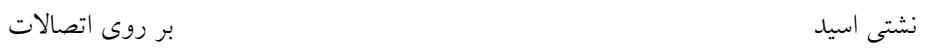

$$
\begin{aligned}
& \sqrt{ }
\end{aligned}
$$

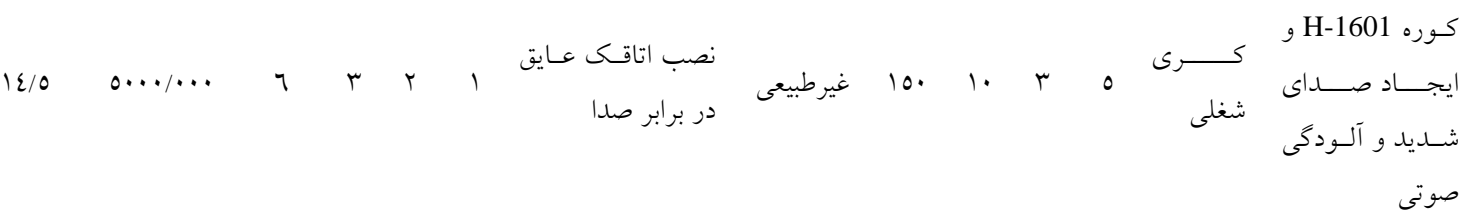

$$
\begin{aligned}
& \text { ل استفاده از كاورهاى }
\end{aligned}
$$

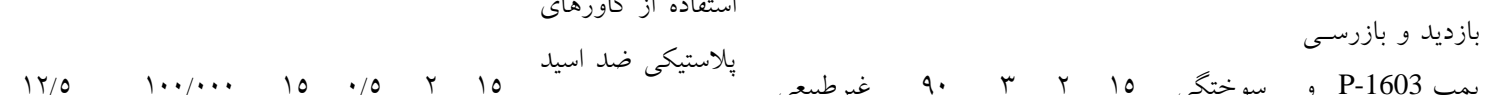

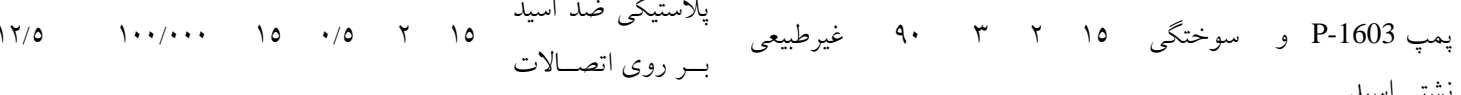

$$
\begin{aligned}
& \text { نشتى اسيد }
\end{aligned}
$$

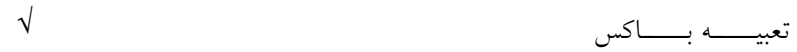

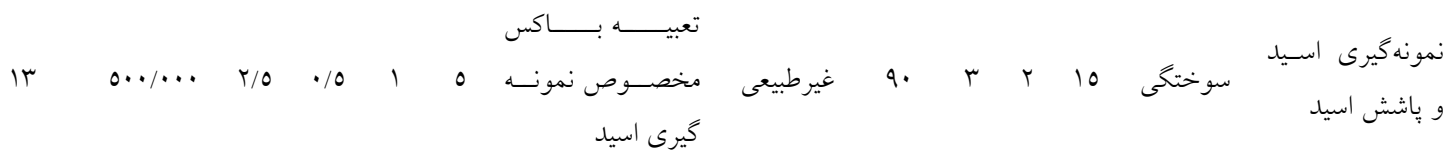

$$
\begin{aligned}
& \checkmark
\end{aligned}
$$

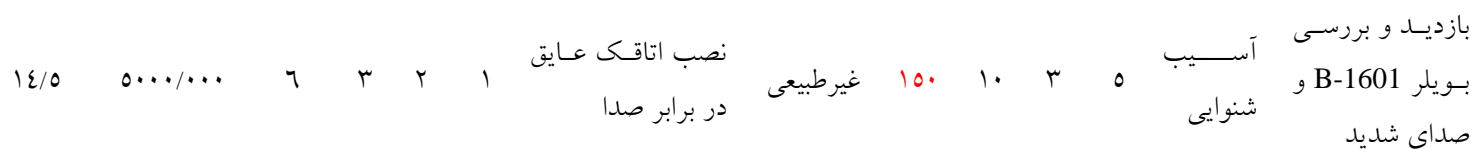

$$
\begin{aligned}
& \checkmark
\end{aligned}
$$

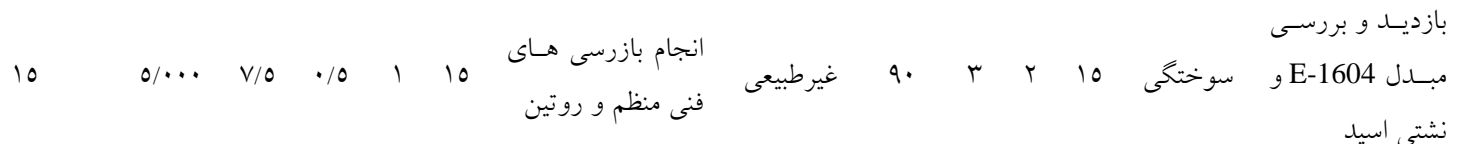

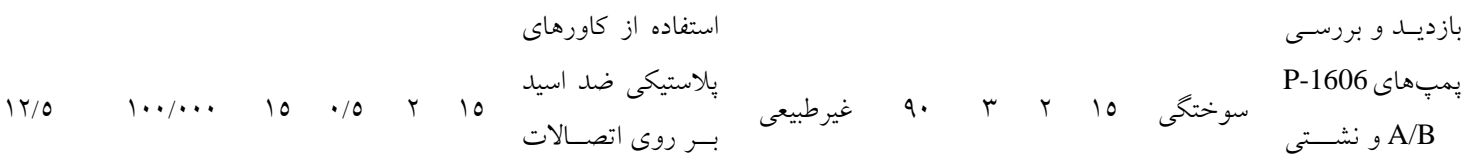

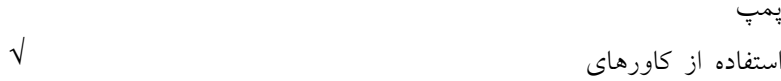

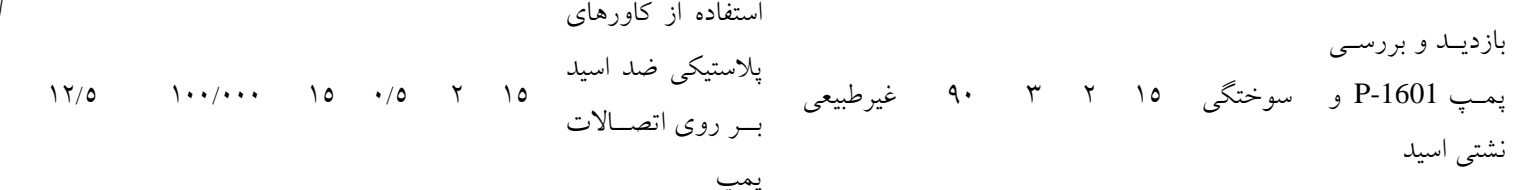

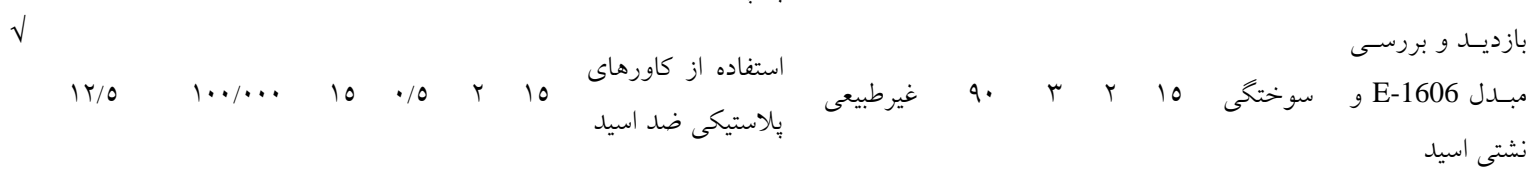

$$
\begin{aligned}
& \sqrt{ }
\end{aligned}
$$

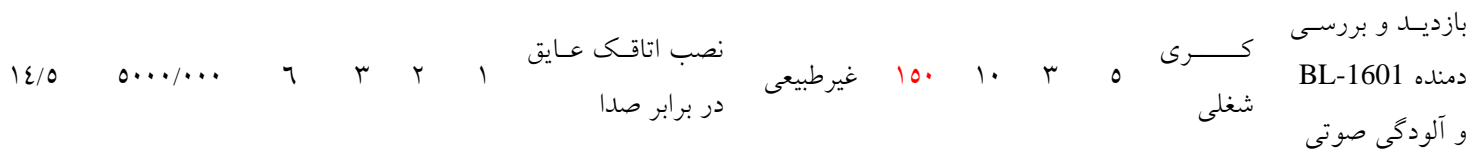


ارزيابى ريسك ايمنى و بهداشت واحد احياى اسيد شركت پالايش نفت آبادان به روش ويليامفاين

$\sqrt{ }$

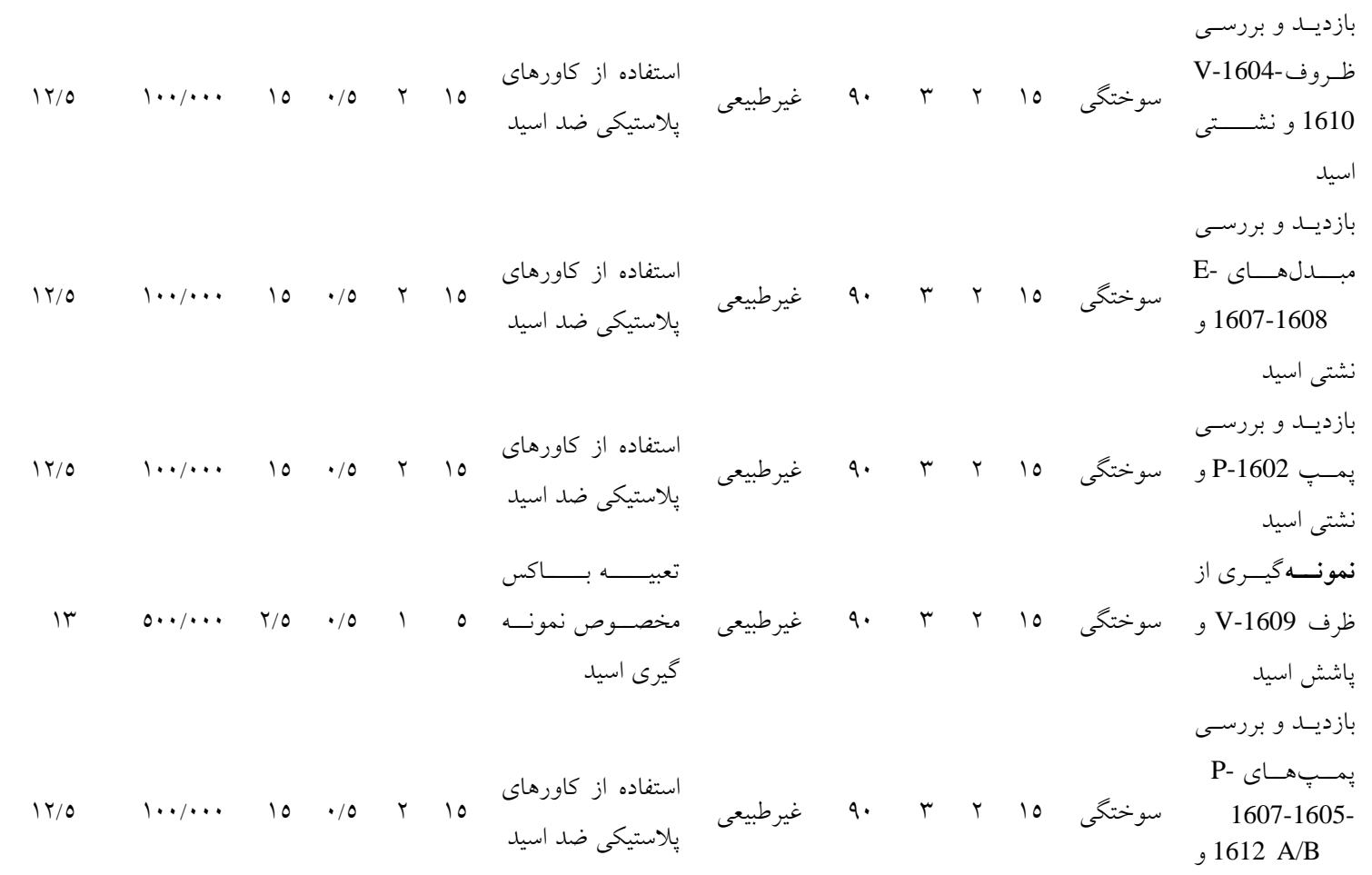

$\sqrt{ }$

$\sqrt{ }$

$\sqrt{ }$

$\checkmark$

$\sqrt{ }$ نشتى اسيد استفاده از ماسـك- هاى ضــ بخـارات 10 اسيدى هاى ضمد بخارات

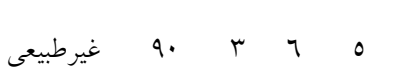

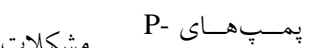

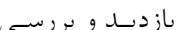
تنفسى 1607-1605g $1612 \mathrm{~A} / \mathrm{B}$

$\sqrt{ }$ استنشاق اسيد

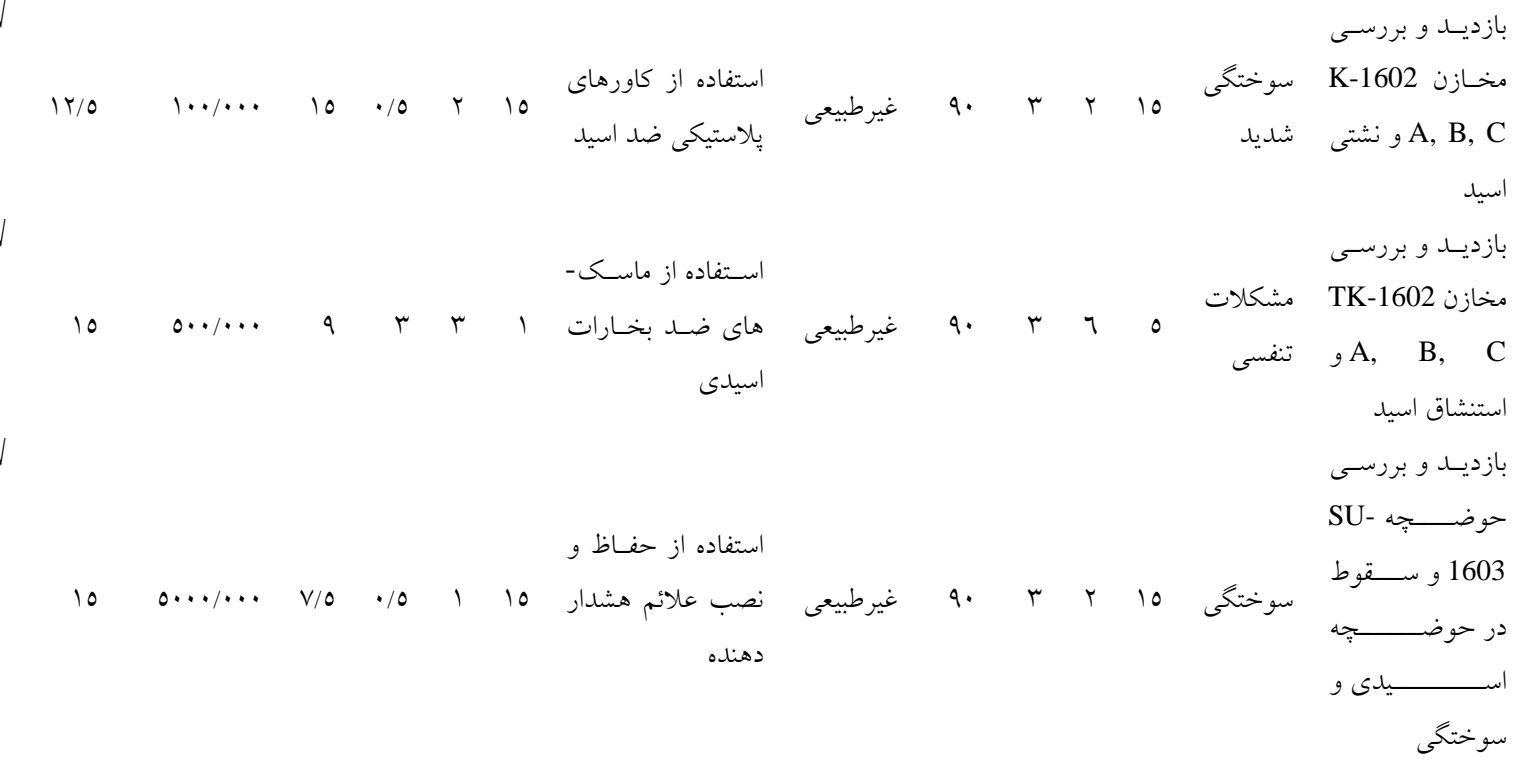


$\checkmark$

$$
\begin{aligned}
& \text { نصــب شــاور و } \\
& \text { اسبرى نازلهاى آب }
\end{aligned}
$$

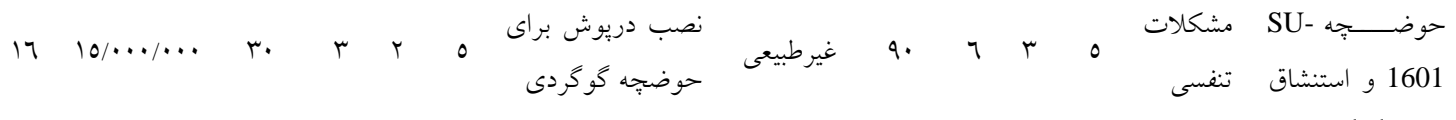
ذرات كوخرد

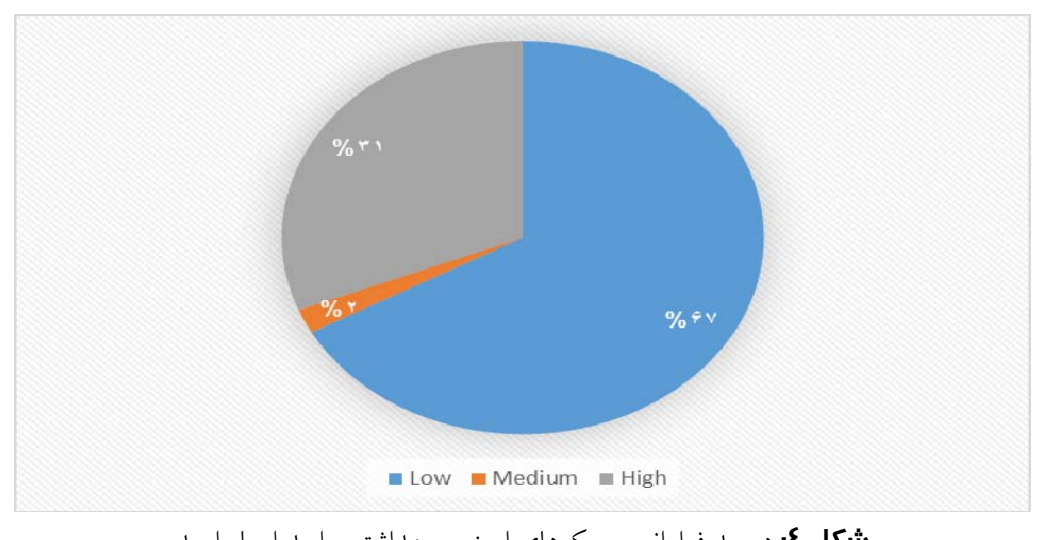

شكل ع: درصد فراوانى ريسكهاى ايمنى و بهداشتى واحد احياء اسيد

از آنجا كه بيشتر مواد مورد استفاده در صنايع نفت، كَاز،

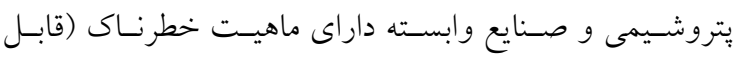

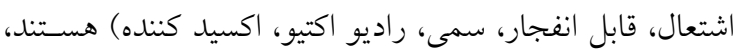

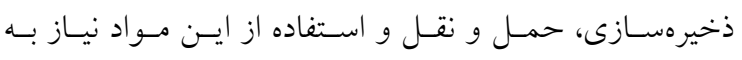

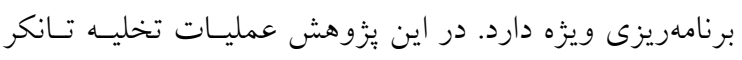

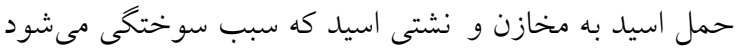

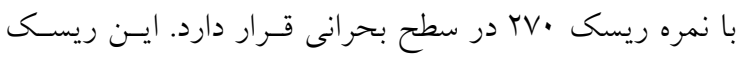

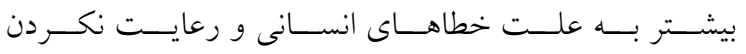

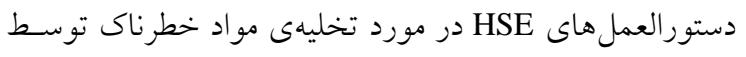

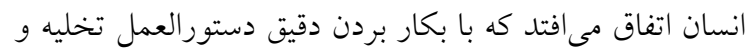
بارگيرى ميزان ريسك به سطح طبيعى بر مى گردد.

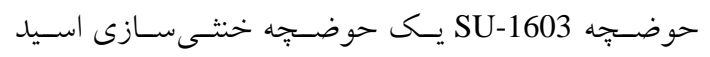

اين يزوهش با هـــف ارزيـابى و مـــيريت خطــر ايمنس و

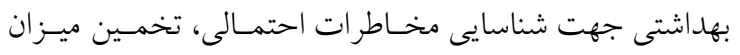

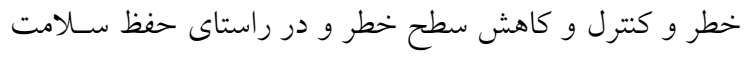

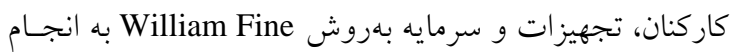

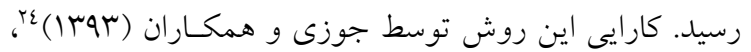

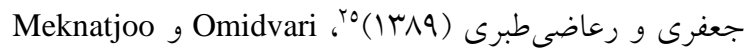

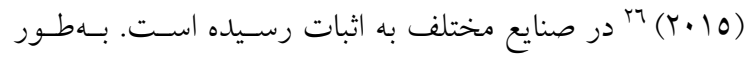

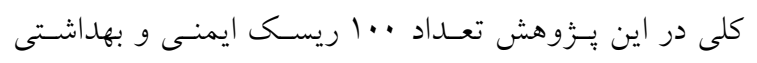

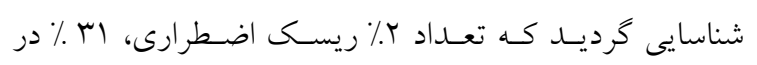

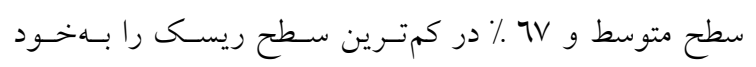
اختصاص دادهاند. 


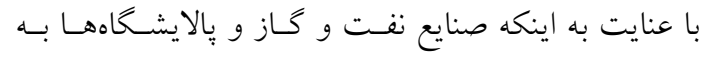

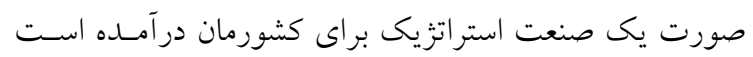
لذا توجهات در اين صنعت به نيروهاى انسانى و محيطزيست كمتر از توجه به خود صنعت مىباشد و در بسـيارى از مـوارد اين صنعت از صرف يكسرى هزينههـا بــراى بهبـود وضـعيت نيروهاى انسانى و محيطزيست سرباز مىزند. از آنجا كـه در دنيا صنايع نفت و كاز جز صنايع با ارزش افزوده بالا مىباشــ

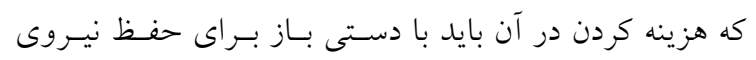
انسانى و محيطزيست صورت كيـرد لـيكن در برخسى مـوارد مشاهده شد كه كوتاهى هايى در اينباره صورت كرفته است. با

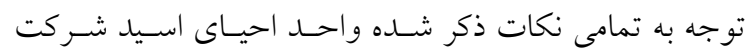

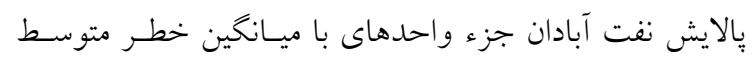

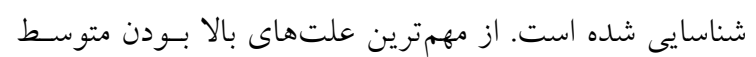

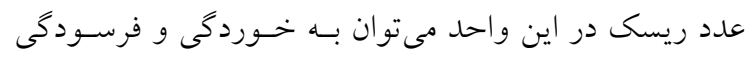
برخى تجهيزات واحد به علت وجود اسيدسولفوريك و عـدم

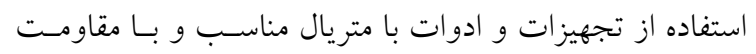
بالا در برابر خورنسدگى اسـيد بـه علـت وجـود تحـريمهـاى اقتصادى و ساير موانع و مشكلات مىباشد. از ديخر علتهاى افزايش ريسك واحد فوق مىتوان به خواص اسيدسولفوريك بهعنو ان يكى اسيد بسـيار قـوى اشـاره كـرد كـهـ داراى اثــرات بهداشتى و زيستمحيطى مضـر زيـادى مسىباشـد. همجنـين بررسى ها نشان داد كه در كليه بخش هاى ايسن واحســ آمـوزش يرسنل بهعنوان يكى از كليدىتـرين نكـات بــراى كـاهش يـا حذف ريسكهاى ايمنى و بهداشت شغلى موجــود مسىباشـد. شايان ذكر است در دوره زمانى انجـام تحقيـق فـوق و انتقـال نتايج به مسولين واحد حوادث رخ داده در واحد فوق به طـرز محسوسى كاهش يافت. با توجه بـه وضـعيت صسنعت مـورد

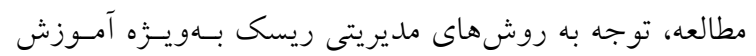
يرسنل در بخششهاى مختلف، تشـكيل تسيم بررسى حادثـه و آناليز علمى حوادث و شبه حوادث، نقـش مهمسى در كـاهش ريسك كلى سيستم خواهد داشت. در نتيجه بيشنهاد مسى شئود
مىباشد، كه يسابهاى اسيدى و اسيدهاى مازاد واحد احيـاى

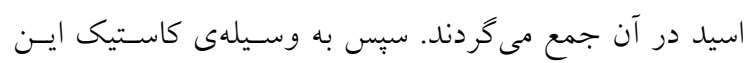

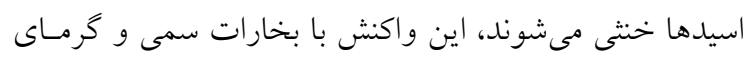
بسيار زيادى همراه است، كه آسيبهاى فراوانى براى كاركنان اين بخش از لحاظ ايمنى و بهداشتى دارد، در نتيجه بازديسا و بررسى حوضجه، SU-1603 و استنشاق كازهاى خنتى سازى و مشكلات تنفسى كه بهوجود مى آيد يكى از ريسكهاى بـالقوه

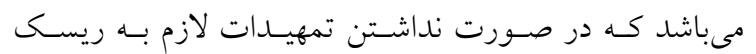
بالفعل تبديل مى شود و آسيبهاى مالى و انسانى بسيار زيادى

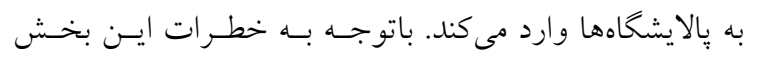

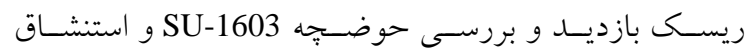
كازهاى خنثى سازى و مشكلات تنفسى با نمره سطح اضطرارى قرار گرفته است. در نتيجه با توجه به احتمال زياد وقوع، شدت اثر، قرار گرفتن در معرض و در نتيجـه بـالا بودن خطر، ضرورى است توجه خاصى به جلو گيرى از وقوع

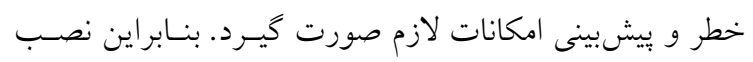

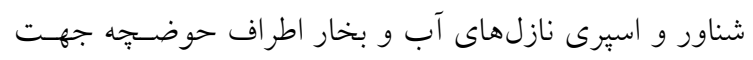
فرو نشست بخارات اسيدى از اقدامات فورى اصلاحى هستند

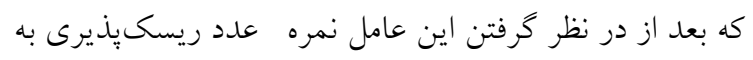

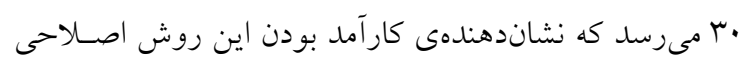
است كه توجيهه اقتصادى نيز دارد.

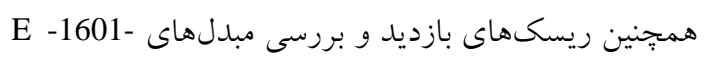

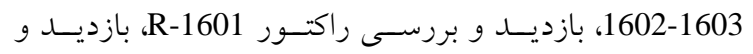
بررسى مبدل E-1606 و بازديد و بررسى بـويلر B-1601 كـهـ

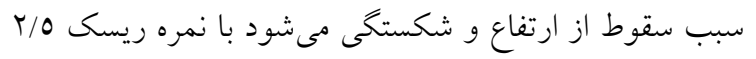
كمترين ميزان ريسك را به خود اختصاص دادهاند زيرا كـه در يالايشخاه آبادان تمهيدات بسيار سخت گيرانهاى براى اين امـر

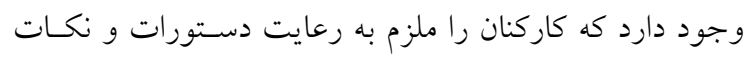
ايمنى در خصوص كار در ارتفاعات مى كند.

\section{تتيجه گيرى}




$$
\begin{aligned}
& \text { خاص واحد و وجود اسيد با خاصيت خورنسـدى بـالا جهـت } \\
& \text { كاهش ريسك هاى موجود بيشنهاد مى گردد. } \\
& \text { ل بكار گيرى سيستمهاى هشداردهنده كه اثربخشى اين } \\
& \text { سيستمها در بسيارى از مواقع تا حد زيـادى بـه جلـو گيرى از } \\
& \text { وقوع حوادث و يا كاهش اثرات منفى آنها كمك مىنمايد. } \\
& \text { ل تعبيه دوشهاى اضطرارى جهت شستشـوى سـريع } \\
& \text { محل سوختخى بـا اسـيد در نقـاط مختلـف واحسـ مطـابق بـا }
\end{aligned}
$$

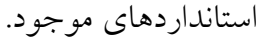$$
\text { تشكر و قدردانى }
$$$$
\text { بدينوسيله از همكارى برسنل محتـرم واحسد احيـاى اسـيد }
$$$$
\text { شركت پالايش نفت آبادان تشكر و قدردانى مىنماييم. }
$$

\section{References}

1. Ezejiofor T.I.N, Iwuala O.E, Nwigwe H.C. Risk assessment: Prevalent Occupational Hazards in Nigerian petroleum oil refining and distribution industry. J. Med. Invest. Pract. 2012; 8:24-829.

2. Li H, Dong K, Jiang H, Sun R, Guo X, Fan Y. Risk Assessment of China's Overseas Oil Refining Investment Using a Fuzzy-Grey Comprehensive Evaluation Method. Sustainability 2017; 9: 1-18.

3. Osabutey D, Obro- Adibo G, Agbodohu W, Kumi P. Analysis of Risk Management Practices in the Oil and Gas Industry in Ghana. Case Study of Tema Oil Refinery (Tor), Eur. J. Bus. Manage. 2013; 5 (29): 139-149.

4. Navaie aznave Z, Omidvari M. Safety Risk assessment in Motor vehicle industries by using William fine and ANPDEMATEL. Iran. Occuo. Health. J. 2017; 14 (1): 57-70 [in Persian].

5. Abbaspour M, Nasiri P, Dana T, Totonchean S. HSE risk assessment and hazard identification in projects of oil and gas industries from construction to production (Case Study: Petro Pars Ltd). J. Environ. Sci. Technol. 2006; 11 (3): 1-13 [in Persian].

6. Ezejiofor T. Risk Assessment: Re-appraisals for Potential Hazards in the Operational Environment and Facilities of Petroleum Refining and Distribution Industry in Nigeria Research and Review. Occup. Med. Health. Affa. 2014; 2:187.

7. Meknatjoo M, Omidvari M. Safety Risk Assessment by using William -Fine method with Compilation Fuzzy

$$
\begin{aligned}
& \text { كه براى كاهش ريسك } \\
& \text { ل اهداف و خط مشىهاى ايمنسى، بهداشـت بايـد بـه } \\
& \text { صورت شفاف بــراى مـــيران ارشــ تشـريح شــده تـا باعـث } \\
& \text { افزايش فرهنگ و دانش ايمنى و بهداشت در بين مديران و در } \\
& \text { يَى آن در ميان بِ سنل گردد. } \\
& \text { ل لظارت دقيق بر اجـراى دسـتورالعمل هـاى ايمنسى و } \\
& \text { بهداشت شغلى و سخت گيرى توسط مسئولين اين بخشها. } \\
& \text { ل به علت بالا بودن ريسك سوختخى با اسيد همجهنين }
\end{aligned}
$$

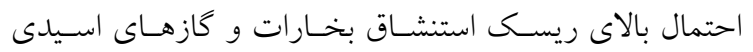

$$
\begin{aligned}
& \text { بيشنهاد مى گردد نفرات از وسايل استحفاظى از جملـه البسـه } \\
& \text { ضد اسيد و ماسكىهاى تنفسى ضد بخــارات اسـيدى اسـتفاده } \\
& \text { نمايند. } \\
& \text { انجام بازرسىهاى فنى از ادوات در دورههاى مـنظم } \\
& \text { و نزديك به هم از نظر زمانى از واحد فوق نيز به علت شرايط }
\end{aligned}
$$

DEMATEL in Machining Process. Iran. Occuo. Health. J. 2015; 12 (5): 31-42 [in Persian].

8. Jozi S.A, Mirsalimi S.M. Environmental risk management of Madkansar Iron Ore Mine in Khorambid County using EFMEA and William Fine integrated approach. J. Manage. Syst. 2016; 1 (1): 19-27 [in Persian].

9. Ebrahimi M.H, Raei M. Conducting Risk assessment by William-Fine method in one of Kermanshah tile factory in 2014, J. Curr. Res. Sci. 2016; 1: 8-13 [in Persian].

10. Halvani G, Ehrampoush M H, Ghaneian M T, Dehghani A, Hesami Arani M. Applying Job Hazard Analysis and William Fine Methods on risks Identification and assessment of Jobs in Hot Rolling Steel, Iran. J. Mazandaran. Univ. Med. Sci. 2017; 26 (145): 293-303[in Persian].

11. Pirsaheb M, Yarmohammadi H, Rostami R, Sohrabi Y. The Evaluation of Safety, Health, and Environmental Risks in Waste Unit of Imam Reza Hospital in Kermanshah Based on William Fines Method, Int. J. Pharm. Technol. 2016; 8 (1): 10910-10917 [in Persian].

12. Jozi S.A, Ka'bzadeh Sh, Iran-Zakhai M. Safety, Health \& Environmental Risk Assessment and Management of Ahwaz Pipe Manufacturing Company via William Fine Method. J. Ilam. Univ. Med. Sci. 2010; 18 (1): 1-8 [in Persian].

13. Ghale S, Khosravi M, Shalbaf M, Taghavi L. Health Safety and Environmental Risk Management cement 


$$
\text { ارزيابى ريسك ايمنى و بهداشت واحد احياى اسيد شركت پالايش نفت آبادان به روش ويليامفاين }
$$

plants. First International Conference of environmental crisis and its solutions, Kish Island, Science and Research Branch 2013: Islamic Azad University, Ahvaz, Iran: 1-9 [in Persian].

14. Samimi S, Yousefi H, Jafarzadeh N. Assessment and management of environmental risks Activities of an oil complex in Abadan Refinery. Proceedings of the 2nd National Conference on Environmental Researches in Iran, Hamedan, Shahid Mofateh University: 1-16 [in Persian].

15. Hataminzhad H. Demographic changes in Khuzestan. Jeo Sci. J. 2006; 1: 119-122 [in Persian].

16. www.arvandfreezone.com.

17. Nikeghbali sisakht N, Sekhavatjo M.S, Roozbehani B, Dadolahi A. Minimization of Air Pollutants Emission from FCCU by Scrubber in Abadan Oil Refinery, Farayandno 2014; 9 (46): 79-95 [in Persian].

18. Werner W, James R.W. The Manufacture of Sulfuric Acid. New York, Reinhold pub 1995: 1- 515.

19. Abadan Oil Refinery Engineering Department, 2011 [in Persian].

20. Jafari Nodoushan R, Kakaei Z, Rezaei H, Khodarahmi F, Kakaei H.A, Hajian N. Risk Assessment of Ilam Gas Refinery Based on William Fine Method in 2012. J. Commun. Health. Res. 2014; 3(1): 49-58 [in Persian].

21. Habibi A, Alizadeh M. Industrail Safety, 4th ed. Fanavaran publisher, Iran, Tehran, 2011:115-118 [in
Persian].

22. Habibi A. Applied Safety and Performance Indicators in Industry. Second Edition, Tehran: Fanavaran Publishing House 2007: 1-385 [in Persian].

23. Pirsaheb M, Zinatizade A.A, Asadi F, Pourhaghighat S, Mohamadi A sharafi K. Assessment and risk, safety, health and environmental management of on shore drilling machines of National Iranian Drilling Company with the method of William Fine. Tech. J. Eng. Appl. Sci. 2015; 5 (3): 127-132 [in Persian].

24. Jozi A, Jafardzadehaghighifard N, Afzali behbahani N. Identify and Assess Environmental Risks Posed by High - Voltage Power Transmission Lines in Urban areas. J. Ilam. Univ. Med. Sci. 2014; 22 (2): 82-92[in Persian].

25. Jafari A.R, Razi Tabari H.R. Case study of risk assessment by William Fein in Power Plants of Abadan Oil Refining Company. The First International Conference on Inspection and Safety in Oil and Energy Industries 2010; Tehran, Iran. - Kimia Energy Conservatives; 1-8 [Persian].

26. Meknatjoo, M, Omidvari, M, 2015, Safety Risk Assessment by using William -Fine method with Compilation Fuzzy DEMATEL in Machining Process, Iran. Occuo. Health. J. Volume 12, Number 5, pp 31-42. [in Persian]. 